\title{
Hubungan Lamanya Mengidap Diabetes Melitus Tipe 2 Terhadap Risiko Jatuh Pada Lansia Di Puskesmas Arjuno Kota Malang
}

\author{
Gusti Yeni Roudhatul Ilmi*, Kurnia Putri Utami, Nurul Aini Rahmawati \\ Program Studi Fisioterapi, Fakultas Ilmu Kesehatan, Universitas Muhammadiyah Malang \\ *Korespondensi: gustiyeni.roudhatulilmi@gmail.com
}

\begin{abstract}
ABSTRAK
Diabetes melitus yaitu salah satu kelompok dari metabolik dengan karakteristik hiperglikemia karena adanya gangguan pada sekresi insulin atau kinerja produksi insulin. Hiperglikemia yang berkelanjutan pada pengidap diabetes melitus akan menyebabkan kerusakan dan disfungsi pada organ lain khususnya pembuluh darah, system musculoskeletal, indera pengelihatan, jantung yang dapat mempengaruhi risiko jatuh pada pengidap diabetes tersebut. Penelitin ini merupakan jenis penelitian observasional dengan metode cross sectional. Dengan menggunakan teknik quota sampling diperoleh jumlah sampel sebanyak 46 orang. Untuk mengukur risiko jatuh dilkukan pengukuran keseimbangan menggunakan Berg Balance Scale. Data status diabetes diperkuat dengan data sekunder dan rekam medis responden di Puskesmas Arjuno Kota Malang. Dari 46 orang sampel terdapat 19 responden (41,3\%) berisiko jatuh tinggi, 22 responden (47,8\%) berisiko jatuh sedang, 5 responden (10,9\%) berisiko jatuh rendah. Setelah dilakukan uji korelasi menggunakan spearman's correlation didapatkan hasil nilai $p=0,000$ yang menunjukan adanya hubungn lamanya mengidap diabetes melitus dengn risiko jatuh dengan nilai $r=0,864$ yang menunjukkaan adanya hubungan sangat kuat antar variabel. Ada hubungan antara lamanya mengidap diabetes melitus tipe 2 tehadap risiko jatuh.
\end{abstract}

Kata Kunci : Risiko jatuh, diabetes melitus tipe 2, Berg Balance Scale.

\section{PENDAHULUAN}

Diabetes melitus (DM) merupakan suatu kelompok penyakit metabolik dengan karakteristik hiperglikemia yang terjadi karena kelainan sekresi insulin, kerja insulin, atau kedua-duanya (American Diabetes Assosiation, 2010). Menurut World Health Organization (WHO) diabetes melitus adalah penyakit metabolik1kronis yang ditandai dengan peningkatan kadar glukosa darah (atau gula darah) yang 1 mengarah dari waktu ke waktu ke kerusakan serius pada jantung,1 pembuluh darah, mata, ginjal dan saraf. Tipe diabetes yang paling umum diabetes melitus tipe 2, dan biasanya 1 pada orang dewasa yang terjadi ketika tubuh menjadi resisten terhadap insulin atau tidak menghasilkan cukup insulin.

Dalam tiga dekade terakhir, prevalensildiabetes mellitus tipe 2 telah meningkat secara dramatis di beberapa negara. Pada pengidap diabetes, akses ke perawatan yang terjangkau termasuk insulin, sangat penting untuk kelangsungan hidup mereka. Dewasa ini penyakit diabetes melitus merupakan salah1satu ancaman terbesar bagi manusia. Badan World Health Organization (WHO) memperkirakan, pada tahun 2000 jumlah pengidap penyakit diabetes melitus yang berusia diatas 20 tahun berjumlah 150 juta orang dan dalam kurun waktu 25 kemudian pada tahun 2025, jumlah itu akan meningkat menjadi 300 juta orang. Ada target yang disepakati secara global untuk menghentikan peningkatan diabetes dan obesitas pada tahun 2025 .

Insulin merupakan hormon1yang bertugas untuk mengatur keseimbangan kadar gula dalam darah. Ketika kadar gula 
darah tinggi dalam beberapa waktu dapat menyebabkan berbagai masalah kesehatan. Dalam jangka waktu pendek dapat menyebabkan hypoglikemia dan ketoacidosis, dan dalam jangka waktu panjang dapat terjadi komplikasi penyakit lain seperti kerusakan pada mata (retinopathy), kerusakan pada saraf (neuropathy), penyakit1ginjal (nefropathy diabetic), meningkatkan risikolpenyakit jantung juga stroke, hingga menyebabkan kematian. Selain itu juga dapat menimbulkan risiko gangguan fungsi kognitif, penurunan1 kekuatan otot, gangguan keseimbangan, dan meningkatkan risiko jatuh pada pengidap penyakit ini.

Tilling et al (2006) menjelaskan semakin lama seseorang mengidap penyakit diabetes melitus kemungkinan1 terjadinya komplikasi penyakit lainnya dan gangguan kesehatan juga meningkat sehingga risiko jatuh pada pengidap penyakit tersebut semakin tinngi.1Chiba $e t$ al (2015) juga melakukan penelitian.1yang serupa tentang faktor risiko yang berhubungan dengan lansia pada kondisi diabetes melitus tipe 2, mendapatkan1hasil yaitu hypoglikemia sebagai faktor risikoljatuh pada lansia dengan kondisi diabetes melitus tipe 2 .

$\begin{array}{ccc}\text { Pada } & \text { tahun } 2012 \text { American } \\ \text { Diabetes } & \text { Assosiation } & \text { menyatakan }\end{array}$ mayoritas penderita1diabetes mellitus tipe 2 berusia 45-64 tahun. Pernyataan tersebut dikaitkan dengan berbagai macam penyakit1degenerative termasuk didalamnya penyakit 1diabetes mellitus. Dengan bertambah usia selain menempatkan seseorang1mudah mengalami diabetes1juga terjadi penurunan kemampuan1 system musculoskeletal, input sensoris, serta perlambatan respon motoris yang menyebabkan keseimbangan1tubuh menurun dan berisiko tinggi untuk jatuh serta mengalami cidera.

Semakin lama mengidap diabetes melitus tipe 2 maka akan meningkatkan terjadinya berbagai macam 11 komplikasi baik mikrovaskuler maupun makrovaskuler sehingga dapat menyebabkan1penurunan keseimbangan tubuh pasien tersebut. Fluktuasi1 gula darah menyebabkan seseorang memiliki risiko jatuh. Komplikasi diabetes1seperti gangguan pengelihatan, terjadinya neuropati pada ekstremitas bawah, juga postural hipotensi yang menyebabkan peningkatan risiko untuk jatuh (Chiba ., et al , 2015).

\section{METODE PENELITIAN}

Penelitian ini merupakan penelitian observasi yang menggunakan cross sectional sebagai desain penelitian. Penelitian observasi yaitu untuk mencari hubungan antara variabel bebas dengan variabel terikat yang analisanya untuk menentukan ada tidaknya hubungan antar variabel sehingga perlu disusun hipotesanya. Sedangkan cross sectional merupakan metode penelitian yang mempelajari tentang dinamika korelasi antar faktor-faktor risiko terhadap efek, dengan metode observasi, atau pada satu waktu sekaligus melakukam pengumpulan data observasi point time approach (Notoatmodjo, 2010)

Mekanisme pengukuran kesimbangan menggunakan Berg Balance Scale (BBS). Penilaian sebuah skala lima poin, mulai 0-4. "0" menunjukkan tingkat terendah dan fungsi "4" tingkat tertinggi fungsi. Jumlah Skor $=56$. Interpretasi skor BBS yaitu jika responden mendapatkan skor 41 - 56 maka risiko jatuh rendah, jika responden mendapatkan skor 21 - 40 maka risiko jatuh sedang dan jika responden mendaptkan skor $0-20$ maka risiko jatuh tinggi. Mekanisme identifikasi responden berdasarkan durasi mengidap diabetes melitus tipe 2 yaitu dengan menggunakan kuesioner. Jika responden mengidap diabetes melitus tipe 2 selama $1-5$ tahun maka masuk dalam durasi pendek, $6-10$ tahun masuk dalam dursi sedang dan $>10$ thun maka masuk dalam durasi panjang (Berg K et al,.1997) 


\section{HASIL PENELITIAN}

Data pada tabel 1 menunjukan mayoritas pengidap diabetes melitus tipe 2 berjenis kelamin perempuan sebanyak 44 orang responden, sedangkan jumlah pengidap diabetes melitus tipe 2 yang berjenis kelamin laki-laki sebanyak 2 orang responden. Jadi dapat disimpulkan bahwa mayoritas responden yang memiliki kriteria adalah perempuan sebanyak 44 responden.

Table 1. Karakteristik responden berdasarkan jenis kelamin

\begin{tabular}{ccc}
\hline & \multicolumn{2}{c}{ Responden } \\
\cline { 2 - 3 } Jenis & $\mathrm{n}$ & $\%$ \\
Kelamin & 2 & 4.3 \\
\hline Perempuan & 44 & 95.7 \\
Laki-laki & 46 & 100.0 \\
Jumlah &
\end{tabular}

$\mathrm{n}=$ jumlah responden $; \%=$ Presentase

Sumber : Hasil pengumpulan data, 2019

Berdasarkan data pada tabel 2 jumlah sampel terbanyak berusia 59-64 tahun sebanyak 19 orang responden, dan jumlah terendah pada responden berumur antara 65-70 tahun sebanyak 5 orang responden. Jadi dapat disimpulkan bahwa jumlah terbanyak distribusi responden berdasarkan umur ialah pasien dengan rentang 59-64 tahun sebanyak 19 orang responden.

Tabel 2. Karakteristik responden berdasarkan usia

\begin{tabular}{ccc}
\hline & \multicolumn{2}{c}{ Responden } \\
\cline { 2 - 3 } Tahun & $\mathrm{N}$ & $\%$ \\
\hline $47-52$ & 10 & 22 \\
$53-58$ & 12 & 26 \\
$59-64$ & 19 & 41 \\
$65-70$ & 5 & 11 \\
\cline { 2 - 3 } Jumlah & 46 & 100.0 \\
\hline
\end{tabular}

$\mathrm{n}=$ Jumlah responden $; \%=$ Presentase

Sumber : Hasil pengumpulan data, 2019

Data pada tabel 3 menunjukan jumlah pengidap diabetes melitus tipe 2 dengan durasi jangka pendek sebanyak 6 orang responden, kemudian dengan durasi sedang sebanyak 16 orang responden, dan pada kelompok durasi jangka panjang sebanyak 24 orang responden. Jadi dapat disimpulkan bahwa jumlah responden banyak ialah pada kelompok durasi jangka panjang sebanyak 24 orang responden.

Tabel 3. Karakteristik responden berdasarkan lamanya mengidap diabetes melitus tipe 2

\begin{tabular}{cccc}
\hline & \multicolumn{3}{c}{ Responden } \\
\cline { 2 - 4 } Durasi & Keterangan & $\mathrm{n}$ & $\%$ \\
\hline 1-5 & $\begin{array}{c}\text { Durasi } \\
\text { Pendek }\end{array}$ & 6 & 13.0 \\
& $\begin{array}{c}\text { Durasi } \\
6-10\end{array}$ & 16 & 34.8 \\
& $\begin{array}{c}\text { Sedang } \\
\text { Durasi }\end{array}$ & 24 & 52.2 \\
Jumlah & $\begin{array}{c}\text { Panjang } \\
\mathrm{n}=\text { Jumlah }\end{array}$ & \multicolumn{2}{c}{ responden ; $\%=$ Presentase } \\
responden \\
Sumber : Hasil pengumpulan data, 2019
\end{tabular}

Data pada tabel 4 menunjukan jumlah pengidap diabetes melitus tipe 2 dengan risiko jatuh rendah dan durasi pendek berjumlah 5 orang responden, jumlah responden dengan risiko jatuh sedang dan durasi sedang berjumlah 19 orang responden, sedangkan pada kelompok risiko jatuh tinggi dan durasi panjang berjumlah 17 orang responden. 
Table 4. Karakteristik responden berdasarkan lamanya mengidap diabetes melitus tipe 2 terhadap risiko jatuh

\begin{tabular}{|c|c|c|c|}
\hline & $\begin{array}{c}\text { Durasi } \\
\text { pendek } \\
(1-5 \\
\text { tahun) }\end{array}$ & $\begin{array}{c}\text { Durasi } \\
\text { sedang } \\
(6-10 \\
\text { tahun })\end{array}$ & $\begin{array}{c}\text { Durasi } \\
\text { panjang } \\
(>10 \\
\text { tahun })\end{array}$ \\
\hline $\begin{array}{l}\text { Risiko } \\
\text { jatuh } \\
\text { rendah } \\
\text { (41-56 } \\
\text { point) } \\
\end{array}$ & 5 & 1 & 0 \\
\hline $\begin{array}{l}\text { Risiko } \\
\text { jatuh } \\
\text { sedang } \\
\text { (21-40 } \\
\text { point) }\end{array}$ & 0 & 19 & 2 \\
\hline $\begin{array}{l}\text { Risiko } \\
\text { jatuh } \\
\text { tinggi (0- } \\
20 \text { point) }\end{array}$ & 0 & 2 & 17 \\
\hline
\end{tabular}

Table 5 Hasil uji normalitas

\begin{tabular}{cl}
\hline $\mathrm{P}$ & Keterangan \\
\hline 0,000 & Tidak Normal \\
\hline
\end{tabular}

Shapiro-Wilk test : $\mathrm{P}=$ nilai hasil normalitas

Sumber : Hasil pengumpulan data, 2019

Hasil uji normalitas pada table 5 diperoleh nilai $\mathrm{P}=0,000$ lebih besar dari 0,05 sehingga dapat disimpulkan data berdistribusi tidak normal.

Tabel 6 hasil uji korelasi

\begin{tabular}{lc}
\hline $\begin{array}{l}\text { Sig }(2 \text {-sided }) \\
\text { correlation }\end{array}$ & Coefficient \\
\hline 0,000 & 0,864 \\
\hline
\end{tabular}

Spearman's correlation

Sumber : Hasil pengumpulan data, 2019

\section{PEMBAHASAN}

Pengidap diabetes melitus tipe 2 mengalami defisiensi insulin yang menghambat transfer glukosa ke sel dalam jaringan tubuh yang menyebabkan rasa lapar sehingga terjadi peningkatan glukosa dalam darah yang menimbulkan hambatan dalam perfusi ke jaringan otot yang akan mengakibatkan jaringan otot kurang mendapatkan suplai oksigen dan nutrisi yang menyebabkan sel kekurangan bahan untuk metabolisme, sehingga energi yang dihasilkan berkurang yang berdampak pada timbulnya kelemahan dan lebih lanjut dapat mengakibatkan atrofi otot. Kelemahan otot menimbulkan gangguan pada keseimbangan tubuh statis maupun dinamis sehingga menyebabkan tubuh goyah dan labil dan meningkatkan risiko jatuh (Jernigan, 2012).

Diabetes melitus tipe 2 memiliki karakteristik terjadinya hiperglikemia, adanya kadar gula yang tinggi dalam darah menyebabkan berbagai gangguan pada system seomatosensorik (visual, vestibular, proprioceptive) dan motorik (musculoskeletal, otot, sendi jaringan lunak) yang dapat mengganggu sistem keseimbangan dan meningkatkan risiko jatuh (Bogdan Timar, 2016).

Hiperglikemia pada pasien penderita diabetes juga mengakibatkan gangguan pada sisten vestibular. Pada telinga bagian dalam terdapat organ labirin yang berfungsi untuk menjaga keseimbangan, mendeteksi perubahan posisi, dan gerakan kepala. Di dalam apparatus vestibularis mengandung endolimfa dan perilimfa juga mengandung sel rambut yang dapat mengalami depolarisasi dan hiperpolarisasi tergantung arah gerakan cairan (Sherwood, 2011).

Terdapat risiko yang terkait dengan diabetes yang mengakibatkan terjadinya gangguan pada proprioseptif. Salah satunya adalah neuropati diabetes yang dampaknya pada sistem saraf menyebabkan perlambatan hantaran saraf dam berkurangnya sensitivitas mengakibatkan terjadinya mati rasa, kesemutan dan nyeri pada kaki, dan meningkatkan risiko kerusakan pada kulit akibat hilangnya sensasi dan mengarah pada gangguan sensorik termasuk kinestetik dan 
proprioseptif. Neuropati diabetic salah satu yang menyebabkan kehilangan sensasi kinestetik dan proprioseptif yang memiliki peranan penting dalam presepsi dan stabilitas akibatnya menyebabkan terjadinya gangguan presepsi dan stabilitas tubuh mempertahankan posisi (Sadaqat et al,. 2014).

\section{KESIMPULAN}

Berdasarkan penelitian yang dilakukan maka dapat disimpulkan bahwa ada hubungan antara lamanya mengidap diabetes melitus tipe 2 terhadap risiko jatuh pada lansia.

\section{DAFTAR PUSTAKA}

American Diabetes Association., (2014). Diagnosis and Classification of Diabetes Melitus. Diabetes Care. 37: 1.

Bogdan Timar, Romulus Timar, Laura Gaita, Cristian Oance, Codrina Levai, Diana Lungeanu (2016) : The Impact of Diabetic Neuropathy on Balance and on the Risk of Falls in Patients with Type 2 Diabetes Mellitus : A Cross-Sectional Study.

Chiba Y,Yoshiyuki Kimbara, Remi Kodera, et al (2015). Risk factor sassociated with falls in elderly patients with type 2 diabetes. Journal of Diabetes and Its Complications. 29898-902.

D’Silva L.J, James Lin, HinrichStaecker, Susan L. Whitney, Patricia M. Kluding. (2016) Impactof Diabetic Complications on Balance and Falls: Contribution of the Vestibular System. Phys Ther.;96:400-409.

Mauk, K.L. (2010) Gerontological nursing competencies for care (2nd ed). Sudbury: Janes and Barlett Publisher.

Roman de Mettelinge T, Cambier D, Calders P, Van Den Noortgate $\mathrm{N}$, et al (2013). Understanding the Relationship between Type 2 Diabetes Mellitus and Falls in Older Adults: A Prospective Cohort Study. Journal of pone PLoS ONE 8(6):e67055. doi: 10.1371

Sadaqat H, Sara Amin, Arshad Nawaz Malik. 2012. Kinesthetic and Proprioceptive Impairments in Diabetic Patient. Journal of Riphah International University Islam abad.

Tilling, L.M.T, Khaled Darawil, Mary Britton.(2005). Falls as acomplication of diabetes mellitus in older people. Journal of Diabetes and Its Complications $20 \quad$ (2006) 158-162Lu F-P.

Timar B, Timar R, Gaiță L, Oancea C, Levai C, Lungeanu D, (2016) The Impactof DiabeticNeuropathy on Balance and on the Risk of Falls in Patientswith Type 2 DiabetesMellitus: A CrossSectional Study. Plos one journal of pone ONE11(4):1371/154654. 